\title{
ЕФЕКТИВНІСТЬ МОТИВАЦІЙНОГО НАВЧАННЯ ПАЦІЄНТІВ ІЗ ФІБРИЛЯЦІЄЮ ПЕРЕДСЕРДЬ ТА АРТЕРІАЛЬНОЮ ГІПЕРТЕНЗІЄЮ
}

\author{
В. А. Антецька, I. П. Савченко, I. В. Смачило, М. В. Степова \\ Чемеровецький медичний коледж \\ ДвНЗ «Тернопільський державний медичний університет \\ імені І. Я. Горбачевського МОЗ Украӥни» \\ ННI медсестринства
}

У статті висвітлено результативність змодельованої програми мотиваційного навчання пацієнтів із фібриляцією передсердь та артеріальною гіпертензією. Встановлено, що проведення мотиваційного навчання із залученням середнього медичного персоналу для таких пацієнтів підвищує їх зацікавленість до свого здоров’я, що врешті-решт приводить до зміни способу життя, регулярного контролю пульсу та артеріального тиску, і як наслідок - покращує якість життя та прихильність до лікування.

\section{EFFECTIVENESS OF PATIENTS’ MOTIVATIONAL TRAINING IN CASE OF ATRIAL FIBRILATION AND HYPERTENSION}

\author{
V. A. Antetska, I. P. Savchenko, I. V. Smachylo, M. V. Stepova \\ Chemerivtsi Medical College \\ I. Horbachevsky Ternopil State Medical University \\ Institute of Nursing
}

\begin{abstract}
This article provides an assessment of the effectiveness of the developed motivational training program in hypertensive patients with atrial fibrilation. It was established that the conducting of motivational training for such patients increases their level of intensity and attitude to health, leading to lifestyle modifications, regular monitoring of blood pressure and pulse, which improves their quality of life and complaens.
\end{abstract}

Вступ. Фібриляція передсердь (ФП) є найпоширенішим хронічним порушенням ритму серця, яке спостерігають у 1-2 \% людей в загальній популяції. На сьогодні від цієї аритмії страждають понад 6 млн європейців, і очікують, що за наступні 50 років захворюваність на ФП стане принаймні удвічі вищою, враховуючи постаріння населення. При веденні хворих із ФП не завжди достатньо уваги приділяють виявленню та корекції причини аритмії, що може суттєво вплинути на вибір оптимального лікування у пацієнтів із ФП [9]. Найпоширенішим і певною мірою недооціненим фоновим серцево-судинним захворюванням у хворих із ФП є артеріальна гіпертензія (АГ). 3 одного боку, вона асоціюється з підвищеним ризиком виникнення ФП, з іншого - зі зростанням ризику серцево-судинних ускладнень [14]. І хоча ФП не включена в перелік станів, від яких залежить рівень додаткового серцево-

(с) В. А. Антецька, І. П. Савченко, І. В. Смачило, М. В. Степова, 2017 судинного ризику в хворих із АГ [3, 14], зате вона визнана одним із станів, які визначають особливості антигіпертензивної терапії, зокрема переваги застосування певних фармакологічних засобів.

У хворих із ФП артеріальну гіпертензію спостерігають значно частіше, ніж у загальній популяції, а її контроль залишається незадовільним. За даними Фремінгемського дослідження, ймовірність виникнення ФП у хворих на АГ збільшується в 1,8 раза [10, 13], а прогресування від пароксизмальної до постійної форми ФП - в 1,52 раза [11]. Логічно припустити, що ефективна і своєчасна профілактика та превентивна терапія основного захворювання, у тому числі АГ, здатна певною мірою відтермінувати виникнення першого епізоду ФП або вплинути на її перебіг.

Одним з основних моментів профілактики АГ залишаються поведінкова терапія і корекція модифікованих факторів ризику зі зміною харчового стерео- 
типу, усуненням шкідливих звичок та підвищенням рухової активності пацієнтів $[2,7]$. Також залишається перспективним мотиваційне навчання самоконтролю хвороби, що і слугувало підставою провести дослідницьку роботу.

Мета роботи - створити і впровадити методику мотиваційного навчання та проаналізувати їі ефективність у пацієнтів аритмічного профілю з АГ із залученням у методично-навчальний процес медсестринського персоналу.

Основна частина. У більшості випадків пацієнти отримують рекомендації в основному від лікаря, медичні сестри раніше рідко брали участь у проведенні профілактичних заходів. Брак інформації $\epsilon$ потенційно небезпечним для здоров'я і життя пацієнта, тому що для ФП на тлі АГ властиве прогресування та розвиток ускладнень, у тому числі загрозливих для життя. Тому хворому та його родичам необхідна повна інформація про методи профілактики і лікування аритмії та АГ. Особиста робота медсестри з пацієнтами базується насамперед на взаємній довірі. Крім того, для налагодження спілкування з хворим неабияке значення мають уважність та доброзичливість медичної сестри [1]. Також важливим є обізнаність у даній галузі, уміння спокійно, правильно і швидко зрозуміти хворого, зосередитись на його проблемах, хворобах і обрати певну тактику поведінки, здатну забезпечити найбільш швидке і повне одужання пацієнта та віддалення рецидивів, покращення якості його життя в цілому.

Якщо пацієнт кардіологічного профілю навчиться самоконтролю і володітиме базовими знаннями щодо власного захворювання, то підвищиться не лише його якість життя, а й збережеться працездатність. Як відомо, методологічною основою навчання самоконтролю $є$ спеціально розроблені структуровані програми $[5,8]$ з чітко обумовленим обсягом і певною послідовністю викладання матеріалу. Програма повинна містити необхідний мінімум інформації, але при цьому передбачати можливість для кожної людини з різними захворюваннями отримати додаткові відомості, опанувати практичні навички (наприклад, користування тонометром, вимірювання частоти пульсу, контроль маси тіла), навіть якщо вони не входять до структури програми [6, 12].

У дослідження було включено 25 осіб чоловічої статі 3 артеріальною гіпертензією та ФП, віком з 38 до 74 років. Для оцінки комплаєнсу пацієнтів до лікування використовували тест Моріскі-Гріна, що включає 4 запитання:
1. Чи забували Ви коли-небудь прийняти препарати?

2. Чи ставитеся Ви іноді неуважно до годин приймання ліків?

3. Чи пропускаєте Ви приймання препаратів, якщо почуваєте себе добре?

4. Якщо Ви почуваєте себе погано після приймання ліків, то чи пропускаєте Ви наступний прийом?

Відповідь «Так» означає 0 балів, «Ні» - 1 бал.

Прихильними до лікування вважали хворих, які набирали 4 бали, неприхильними - менше 3.

Наша програма включала 3 розділи: інформація про хвороби серця, інформація про АГ, інформація про модифіковані фактори ризику та основні методи профілактики хвороб. Для кожного розділу була сформульована мета, питання для обговорення, набір наочних матеріалів і педагогічних прийомів, спрямованих на засвоєння, повторення та закріплення знань і навичок. Програма тривала впродовж 3 днів, з яких 2 дні - робота в групі, 1 день - індивідуальне мотиваційне заняття. Методи викладання матеріалу: інтерактивна лекція/бесіда, інтерактивний семінар, практичні заняття з медичною сестрою про вимірювання АТ, пульсу, обчислення індексу маси тіла та ін. Використовували мультимедійні й інші технічні засоби навчання, методичні розробки, відеофільми, відеоролики, буклети, освітні статті, брошури.

Слід зазначити, що ВООЗ офіційно визнала навчання повноправним методом лікування хронічних захворювань, рівнозначним медикаментозному та хірургічному. Було введено термін «терапевтичне навчання пацієнтів». У нашому дослідженні оцінку ефективності навчання проводили після його завершення за такими критеріями:

а) рівень інтенсивності ставлення до здоров'я (загальна шкала тестової методики «Індекс ставлення до здоров'я», С. Д. Дерябо, В. О. Ясвин) [3];

б) коливання рівня артеріального тиску (аналіз щоденника пацієнта);

в) коливання частоти пульсу на променевій артерії із додатковим визначенням дефіциту пульсу.

У пацієнтів із фібриляцією передсердь, які були включені в дослідження, окрім артеріальної гіпертензії, виявлено інші фактори ризику: надмірна маса тіла (52 \%), стрес (68 \%), тютюнокуріння (48 \%) та надмірне споживання солі (44 \%). Крім того, 10 пацієнтів не реєстрували щоденно рівень артеріального тиску й пульсу, а 8 хворих не вміли користуватися тономет- 
ром. Жоден із хворих не вів свій особистий щоденник здоров'я, де 6 занотовував показники артеріального тиску і пульсу, харчовий режим, дозування і час приймання медикаментів, що б подовжило якість і тривалість життя пацієнта. Варто також зауважити, що практично всі пацієнти підтвердили існування зв'язку між рівнем артеріального тиску і аритмією, але ігнорували у них їх наявність. Серед пацієнтів, які були включені в дослідження, 52 \% були прихильними до лікування, низький рівень комплаєнсу відзначали у 48 \% хворих. Кожному хворому було проведено мотиваційне навчання. Перший день клініко-інформаційний, який був орієнтований на ознайомлення пацієнтів з інформацією про аритмію (ФП), вплив стресу на провокування пароксизму ФП, необхідність дотримуватися медикаментозного підходу «таблетка в кишені» (pill-in-the-pocket). Проводилося визначення індивідуальних труднощів, з якими пацієнти стикаються під час лікування, і обмін досвідом лікування. Другий день - ознайомлення пацієнтів з інформацією про артеріальну гіпертензію, ії вплив на персистенцію аритмії, особливості впливу фізичного та психоемоційного навантаження при по- єднанні патологій, заповнення таблиць учасниками тренінгу із зазначенням переваг та труднощів дотримання лікування, шляхів їх подолання - при активному залученні й співпраці із середнім медичним персоналом. Третій день - індивідуальне формування свідомого розуміння необхідності лікування, виокремлення основних мотивацій, бажання і спроможності виконувати медичні рекомендації та прагнення до здоров'я, формулювання конкретних цілей на найближче майбутнє та заходи їх реалізації. Через 6 місяців було проаналізовано щоденники пацієнтів та проанкетовано на рівень інтенсивності ставлення до здоров'я. Після завершення програми встановлено значне зменшення питомої ваги пацієнтів із низьким рівнем комплаєнсу, яка становила $12 \%$.

Через 6 місяців після завершення програми було виявлено збільшення рівня інтенсивності ставлення до свого здоров'я у пацієнтів із фібриляцією передсердь на тлі гіпертонічної хвороби (табл. 1). Високий рівень ставлення до здоров'я після участі в програмі у пацієнтів зріс на $16 \%$, тоді як низький рівень - зменшився на $36 \%$, середній рівень був у 52 \% (порівняно з $32 \%$ до проведення програми).

\section{Таблиця 1. Рівень інтенсивності ставлення до здоров'я у пацієнтів із фібриляцією передсердь та артеріальною гіпертензією}

\begin{tabular}{|l|c|c|}
\hline $\begin{array}{c}\text { Рівень інтенсивності ставлення } \\
\text { до здоров'я }\end{array}$ & До проведення навчання, \% & $\begin{array}{c}\text { Через 6 місяців після проведення } \\
\text { навчання, \% }\end{array}$ \\
\hline Високий & 20 & 36 \\
\hline Середній & 32 & 52 \\
\hline Низький & 48 & 12 \\
\hline
\end{tabular}

Аналіз щоденників пацієнтів показав, що лише у 5 пацієнтів протягом 6 місяців були значні коливання артеріального тиску та пульсу. Аналіз харчового режиму показав дотримання рекомендацій медикаментозного підходу «pill-in-the-pocket» у 36 \% пацієнтів, незначимі порушення режиму праці та відпочинку, які не зіставлялися з коливанням частоти серцевих скорочень і пульсу, у 44 \% хворих, та відсутність моніторування АТ - у 24 \% хворих. Аналіз основних факторів ризику свідчив про модифікацію способу життя хворих (збільшення тривалості відпочинку протягом дня, тривалість сну не менше 7 годин, щоденний моніторинг АТ, дотримання раціонального харчування, зниження інтенсивності тютюнокуріння) у 68 \% хворих, що супроводжувалося нормалізацією
АТ у $28 \%$ респондентів. Варто зазначити позитивний вплив проведеного навчання на відмову від тютюнокуріння (у 3 хворих), а також зменшення пачко-днів (у 12 пацієнтів).

Висновки. Проведення мотиваційного навчання лікарем та медсестрою для пацієнтів із фібриляцією передсердь на тлі артеріальної гіпертензії підвищує їх рівень інтенсивності ставлення до здоров'я і супроводжується модифікацією способу життя (уникнення психоемоційних подразників, збільшення тривалості відпочинку і сну, дотримання раціонального харчування, відмова від тютюнокуріння), регулярним контролем частоти серцевих скорочень і артеріального тиску, що покращує якість життя таких хворих. 


\section{СПИСОК ЛІТЕРАТУРИ}

1. Боцюк Н. Є. Особливості організації роботи дільничної медичної сестри з профілактики та лікування гіпертонічної хвороби / Н. Є. Боцюк, К. В. Тіхонова // Медсестринство. - 2015. - № 2. - С. 50-52.

2. Вознесенская Т. Г. Расстройства пищевого поведения при ожирении и их коррекция / Т. Г. Вознесенская // Ожирение и метаболизм. - 2004. - № 2. - С. 2-6.

3. Дерябо С. Д. Психологический тест «Индекс отношения к здоровью» / С. Д. Дерябо, В.А.Ясвин // Прикладная психология. - 2000. - С. 42-51.

4. Жарінов О. Й. Артеріальна гіпертензія і фібриляція передсердь / О. Й. Жарінов // Артеріальна гіпертензія. 2011. - № 5 (19). - С. 3-9.

5. Обучение больных диабетом: синтез доказательной медицины и психологического подхода / А. Ю. Майоров, Е.В.Суркова, О. Г. Мотовилин [и др.] // Сахарный диабет. 2011. - № 1. - С. 46-49.

6. Матвейчева А. О. Оцінка мотиваційного навчання пацієнтів з гіпертонічною хворобою та аліментарним ожирінням / А. О. Матвейчева, В. Я. Пушкін, С. Р. Касіян // Медсестринство. - 2016. - № 1. - С. 36-39.

7. Старостина Е. Г. Ожирение как психосоматическое заболевание / Е. Г. Старостина // Ожирение и метаболизм. 2005. - № 3. - С. 18-23.

8. Терапевтическое обучение больных сахарным диабетом / И. И. Дедов, Е. В. Суркова, А. Ю. Майоров [и др.]. М. : Реа-фарм, 2004. - 193 с.
9. Уніфікований клінічний протокол первинної, вторинної (спеціалізованої) та третинної (високоспеціалізованої) медичної допомоги «Фібриляція передсердь» : наказ МОЗ України від 15.06.2016 р. № 597.

10. Independent risk factors for atrial fibrillation in a population-based cohort: the Framingham Heart Study / E. J. Benjamin, D. Levy, S. M. Vaziri [et al.] // JAMA. - 1994. Vol. 271. - P. 840-844.

11. Progression from paroxysmal to persistent atrial fibrillation clinical correlates and prognosis / C. B. De Vos, R. Pisters, R. Nieuwlaat [et al.] // J. Am. Coll. Cardiol. - 2010. Vol. 55. - P. 725-731.

12. ISPAD Clinical Practice Consensus Guidelines 2009 Compendium. Introduction / R. Hanas, K. C. Donaghue, G. Klingensmith [et al.] // Pediatr. Diabetes. - 2009. Vol. 10, Suppl. 12. - P. 1-2.

13. Prevalence, incidence, prognosis, and predisposing conditions for atrial fibrillation: population-based estimates / W. B. Kannel, P. F. Wolf, E. J. Benjamin, D. Levy // Am. J. Cardiol. 1998. - Vol. 82. - P. 2N-9N.

14. The Task Force for the management of arterial hypertension of the European Society of Hypertension and of the European Society of Cardiology. 2007 Guidelines for the management of arterial hypertension // Eur. Heart J. 2007. - Vol. 28. - P. 1462-1536.

Отримано 08.09.17 